\title{
LITERATURE AND VALUES
}

Papers from the Colloquium of the International Comparative Literature Association held at the University of Sussex, August 1985

Edited

by

HOLGER M. KLEIN and ANTHONY K. THORBLY 



\section{TABLE DES MATIÈRES - CONTENTS}

\section{EDITORIAL}

$\begin{array}{ll}\text { Preface } & 7\end{array}$

Max Bilen, L'écriture comme mode de vie . . . . . . . . . . . 13

A. OWEN AldrIDGE, Irving Babbitt and the Standards of Aesthetic Judgment . . . . . . . . . . . . . . . . . . . 23

Abdullah Moutasim Abdul-Fatah, The Literary and Cultural Criticism of Raymond Williams . . . . . . . . . . . 33

GraHam Good, The American Reception of European Modernism 41

Monica SPIRIdon, Literary Criticism and the Magnifying Glass of Sociology . . . . . . . . . . . . . . . 53

MARLIes KRONEGger, Metaphysics and Literature in Tymieniecka's Poetica Nova . . . . . . . . . . . . . . . . . . . . 61

Antonto Blanch, Metaphysical Values in Modern Poetry . . . 71

JoHn MAIER, Gilgamesh: Anonymous Tradition and Authorial Value 83

K. Chellappan, The Interplay of Ethical and Aesthetic Values in the Tamil Literary Tradition _. . . . . . . . . . . . . 97

Gurbhagat Singr, Social Values and Sign Systems in Medieval Sikh Literature . . . . . . . . . . . . . . . . . . . . . 107

ENIKő Molnár BASA, The National Epic as a Retelling of History 115

Olatubosun Ogunsanwo, Transcending History: Achebe's Trilogy 127

Sonia LeE, Changes in the Mother Image in West African Fiction . 139

V. Harger-Grinling and A. R. ChadWICK, History Re-Interpreted:

Hébert's Kamouraska and Bourin's Très Sage Héloise . . . . 151

IsAo SATO, The Use of Shakespeare in Japan's Kabuki Drama . . 159

Rudolf E. Kuenzli, The Norm-breaking Function of Literature 169

ERduute Wenzel White, Border Crossings: Wühr's The False Book 183

Trbor Fabiny, The Emblem: Document of Bad Taste or Medium of Artistic Value? . . . . . . . . . . . . . . . . . . . . 191 
Amrya Dev, Popular Style: Introduction to a Bengali Case-Study 263 Wm NeEtens, Politics, Poetics, and the Popular Text: The Ragged Trousered Philanthropists . . . . . . . . . . . . . . . . 211

Michael Cardy, Beyond Documentation: Emile Zola and D. H. Lawrence . 225

Peter E. Firchow, From German to "Germhun": Reflections on a Literary Stereotype before 1914 . . . . . . . . . . . 233

Reed B. Merril.L, Darkness at Noon and the Political Novel . . 245 FrederICK, J. HARRIS, Linguistic Reality - Historical Reality: Genet, Céline, Grass . . . . . . . . . . . . . . . . . . 257

Elizabeth C. Hesson, Revolution, Art, and Politics: Peter Weiss 275 Hussam AL-KhateEb, Politics and the Rise of the Syrian Short Story 287 Aduke Grace Adebayo, The Social Function of the African Novel 297 AnNette L. Combrink, Socio-cultural and Political Values in Modern South-African Drama ............. 311 JoHN T. DoRSEY, Atomic Bomb Literature in Japan and the West 325 Subroto Ray, Literature as a Mirror of Socio-aesthetic Evolution 335 Thomas Dilworth, The City at the Centre of The Anathemata . . 345 ZIVA BEN-Porat, History in Representations of Jerusalem in Modern Hebrew Poetry . . . . . . . . . . . . . . . . . 353

Holger M. KLeIN, The Historical Poem: General Approaches and a Sample Analysis (Aragon) . . . . . . . . . . . . . . 359

SWAPAN MAJUMdar, National Literature in a Multilingual Nation: The Indian Experience . . . . . . . . . . . . . . . . . . 373 ANNe Hudson Jones, Literary Value: The Lesson of Medical Ethics 383 Juldette Hassine, L'Enseignement de la littérature dans les milieus défavorisés

Mair E. Verthuy and Jennifer Waelti-Walters, Critical Practice and the Transmission of Culture

INDEX 


\section{PREFACE}

Following immediately after the XIth Congress in Paris, August 1985, the ICLA held a Colloquium at the University of Sussex, organised and hosted by Anthony Thorlby on behalf of the BCLA. The subject was "Literature and Values", and the aim was to provide a rather smaller, more intimate occasion for participants in the main event in France to come together on a residential campus in order to discuss an important topic of common concern.

Some sixty papers were read in a number of seminar groups devoted to different aspects of the question; moreover, there were four plenary lectures. As one might have expected, the grounds of evaluation were found to be very diverse, being in one case social, political, or national, in another abstract, metaphysical, or religious; they have varied from critic to critic, text to text, epoch to epoch. No 'conclusions' were reached, but the ramifications of the question of values were explored and better understood; and the opportunities for personal contact were appreciated and widely used. Thus there existed, for three highly enjoyable days, a close, serious-minded but friendly and relaxed international academic community sharing lifestyle and scholarly objectives alike.

Originally there had been no intention of publishing the Sussex papers. Quite a number of contributions were never meant for this purpose, others already destined for publication elsewhere. Yet there remained a sizeable body of work which particularly the outgoing ICLA President, György M. Vajda, strongly felt should be made available in print, and it is in 
the main thanks to the enthusiasm and enterprise of Neohelicon's editors that the present volume was made possible. It cannot, under the circumstances, reflect the various seminar groups and their sequence of sessions, but gives fairly representative samples of the issues and aspects raised and the approaches and methods applied in the course of the Colloquium at large.

These things take time, and the course of publication never does run smooth. Also, many contributions had to be shortened in order to accommodate all the available material. For a time it even seemed indicated to split the volume into two, one half to appear in Neohelicon, the other in New Comparison. However, eventually the publication in this one volume, surely the best solution, was established as viable and gladly adopted. Everyone showed a praiseworthy spirit of understanding and cooperation and submitting this collection of essays to the public, we want to thank for their help not only the editors of Neohelicon and its publishers, but also all the contributors. Special thanks are due to the ICLA Publications Committee for generously contributing towards the typing costs. 